\title{
Analysis of the Impact of Urban Development on River Water Quality Case Study of the Pesanggrahan River
}

\author{
Muslim Aminuddin ${ }^{1}$, Chotib ${ }^{1}$ \\ \{muslim.aminuddin1993@gmail.com ${ }^{1}$,Chotib@hotmail.com²
}

Urban Development Study Program, Universitas Indonesia, Kampus UI Salemba, Jakarta, Indonesia ${ }^{1,2}$

\begin{abstract}
The Pesanggrahan River from its width characteristics is an intermediate river. The chemical and biological contents of Pesanggrahan River water show that the Pesanggrahan River has been polluted. Water pollution in the Pesanggrahan River is greater in the downstream area, which is due to the accumulation of chemical compounds from industrial and domestic waste. Most of the Pesanggrahan Watershed are residential areas. City development in the Pesanggrahan Watershed has a major influence on the decline in the water quality of the Pesanggrahan River. The biggest development occurred in the period of 2004-2010. Then, in the 2010-2013 period the development was more on the changes in the structure of the Pesanggrahan River flow, namely on river widening and straightening. The area in the Pesanggrahan Watershed is widely used as an illegal industrial area, thus, violating existing spatial provisions. The role of the Jakarta City Government in maintaining river water quality is in the function of building and supervising buildings that violate the rules. This refers to the granting of permits and finally to prosecution of parties who violate and play a role in decreasing the quality of the Pesanggrahan River water.
\end{abstract}

Keywords: Pesanggrahan River, Pesanggrahan Watershed, water quality

\section{Introduction}

The problems caused by pollution that occur in the Pesanggrahan River cannot be separated from the role of buildings built in the area. Therefore, it is necessary to identify water quality which will later be linked to the pattern of urban development in the Pesanggrahan River. The process of identifying water quality is done by using the Water Quality Index (WQI) calculation found in the Pesanggrahan River. The indicators observed in the Water Quality Index are (Kannel, Lee, Lee, Kanel, \& Khan, 2007): water temperature, pH, dissolved oxygen (DO), total dissolved solids (TDS), total suspended solids (TSS), water hardness, Nitrate (NO3), Nitrite (NO2-), biochemical oxygen demand (BOD), chemical oxygen demand as O2 (COD), Fecal Coliform Bacteria, and Total Col iform Bacteria.

Water Quality Index is used by many developing countries because it has analytical costs involved, which can be a limiting factor for water quality assessment with a small budget. Water Quality Index in this study is used as a reference to determine the effect of development around the Watershed Pesanggrahan on environmental degradation in water. So that in the future the DKI Jakarta Government can take steps in regulating urban development and returning the 
function of the Pesanggrahan River to its original function by considering the quality of water available at the Watershed, especially the Pesanggrahan River.

\section{Materials and methods}

This research was conducted using qualitative and quantitative approaches using field survey methods. The survey method is an investigation conducted to obtain facts from the symptoms that exist and look for facts. The survey method dissects and skins and recognizes problems as well as obtaining justification for the conditions and practices that are taking place. The survey method also evaluates and compares things that people have done in dealing with similar situations or problems and the results can be used in making plans and making decisions in the future (Nazir, 2009).

Sampling was carried out along the Pesanggrahan River. The distance between one sampling point and another point is about 500-700 meters. The distance was chosen so that data on the chemical and biological compounds that are present in the Pesanggrahan River water can be clearly known. Therefore the total samples obtained in this river study is 37 observation points knowning that the length of the Pesanggrahan River in the urban area of DKI Jakarta is \pm 20 $\mathrm{km}$.

Pesanggrahan River water sampling is carried out in the Pesanggrahan River Watershed (DAS) area which covers four districts; Pesanggrahan District, Kebayoran Lama District, Kebon Jeruk District, and Kembangan District. Actually, the urban headwaters of the Pesanggrahan River are in the Cilandak area, but Watershed, which is located in that area, is part of the entry area in the Tangerang Regency, Banten Province.

The location of this study was chosen because the Watershed Pesanggrahan has urban characteristics and the Pesanggrahan River flows through dense residential areas.

\section{Result and discussion}

\subsection{Physical Analysis}

Pesanggrahan River has a complex system in the urban water system in DKI Jakarta. Judging from the classification described by Kern (1994), Pesanggrahan River is part of the medium river classification. In the process of field observations, the width of the Pesanggrahan River ranges from 10-20 meters in almost all parts of the Pesanggrahan River, except at points 24 and 37 , which are tributary branches which have a width of $20-40 \mathrm{~m}$.

A river that is in a branching with a tributary usually has a river width that is relatively larger compared to other watersheds. This is caused by several factors such as erosion caused by the flow of the river that erodes the river border or river banks

The regularity of the Pesanggrahan River flow, according to the classification described by Rosgen (1996) in Maryono (2017), is a straight - type river, this can be seen with the Pesanggrahan River flow pattern that is described and viewed using the help of the Google Earth application and also a map of the Regional Spatial Plan DKI Jakarta which describes the Pesanggrahan River is in type $\mathrm{G}$ with a slope of $0-2 \%$. The slope is usually located in the 
Watershed area which is upstream of the river. So it has other characteristics, namely the river flow velocity which tends to be slower compared to the downstream areas of the Pesanggrahan River in the Bogor and Depok regions.

\subsection{Water Quality Index of the Pesanggrahan River}

\section{Temperature}

The highest value of the observation of the water temperature of the Pesanggrahan River is at observation point 27 , which is at the observation point area behind the Belmont Residence Apartment with a temperature value of $31^{\circ} \mathrm{C}$. The meaning is not clear Consider revising, and the lowest value is at observation point 1 or DKI Jakarta's upstream urban Pesanggrahan River with a temperature of $28^{\circ} \mathrm{C}$ and the low value can be caused by weather factors where at $1-8$ observations are observed after rain. The average temperature in the study of the Pesanggrahan River is $29.45^{\circ} \mathrm{C}$.

Calculation of the temperature value is very difficult to identify the cause, because many factors affect the temperature value of water. Besides the influence of nature factor such as rain and heat weather can also affect water temperature. However, if the weather conditions are relatively stable, the existing conditions of the Watershed Pesanggrahan can be identified, whether the Watershed Pesanggrahan is an area that has an area with good ecosystem conditions or not. The influence of ecosystems such as trees and plants can cause water shad to be a low water surface temperature value. Conversely, if the condition of the Watershed Pesanggrahan does not exist or a bad ecosystem is found / there are no trees, then the surface temperature value of the Pesanggrahan River water tends to follow the existing air temperature. The influence of basic chemical compounds (usually in the form of detergents) can theoretically cause the condition of the relative temperature of the water to be higher than the average value of the existing air temperature.

\section{pH}

The highest value of the observation results of the water $\mathrm{pH}$ of the Pesanggrahan River is at observation point 37 which is the observation point area downstream of the Pesanggrahan River with a $\mathrm{pH}$ value of 8.70 or having alkaline properties, and the lowest $\mathrm{pH}$ value of the water of the Pesanggrahan River is at observation point 1 or urban DKI Jakarta Sungai Pesanggrahan with a $\mathrm{pH}$ of 7.2 having normal alkaline properties. The average $\mathrm{pH}$ in the study of the Pesanggrahan River is $\mathrm{pH} 7.84$. The increase in acidity $(\mathrm{pH})$, which has a tendency to increase, can be ascertained due to the increasing number of chemical compounds with alkaline content that is discharged into the Pesanggrahan River at each point downstream of the Pesanggrahan River. These basic chemical compounds can all be found in detergents or cleaning agents, both from domestic and industrial waste products. $\mathrm{pH}$ is a chemical property that is influenced by the content / mixing of a substance's properties in proportion to volume.

\section{Dissolved Oxygen}

Increased diffusion of oxygen or Dissolved Oxygen from the air into the waters is usually caused by wind, falling rain to the surface, temperature, pressure, and the content of various dissolved ions that can affect the level of dissolved oxygen. The following are the results of the measurement of dissolved oxygen in the water of the Pesanggrahan River. 
The highest value from the observation of Dissolved Oxygen (DO) in Pesanggrahan River water is at observation points $1,2,3$, and 5 , namely in the upstream urban observation point areas of DKI Jakarta Pesanggrahan River with a DO value of $3.50 \mathrm{mg} / \mathrm{L}$. This point can be said to be the cleanest point and has a Watershed (DAS) tendency with a fairly good ecosystem, and the lowest DO value of Pesanggrahan River water is at observation points 36 and 37, namely the downstream observation points of the Pesanggrahan River with DO value of $2.00 \mathrm{mg} / \mathrm{L}$. Watershed at this point tends not to have a good ecosystem with the existing condition of the Pesanggrahan River floodgate, where the garbage is carried by the Pesanggrahan River, or transported or accommodated (the existing condition at point 36 is a flood gate and a "taman kota" landfill, kembangan). The average value of Dissolve Oxygen in the Pesanggrahan River water study is $2.75 \mathrm{mg} / \mathrm{L}$.

The low value of Dissolved Oxygen in river water is caused by accumulated garbage, a reduction in plant vegetation that is always decreasing in the Watershed Pesanggrahan and waste factor that is discharged directly in the Pesanggrahan River. In addition, the low value of Dissolved Oxygen (DO) proves that the Pesanggrahan River has been polluted and the aquatic organisms that live in it are disturbed or in other words aquatic organisms (for example: fish and bacteria) in the Pesanggrahan River flow decline, which is directly proportional to the declined oxygen content.

\section{Biochemical Oxygen Demand (BOD) and Chemical Oxygen Demand (COD)}

The highest value of the observation of Biochemical Oxygen Demand (BOD) of Pesanggrahan River water is at observation point 26, which is the observation point of the Permata Srengseng complex with the Biochemical Oxygen Demand value of $5.50 \mathrm{mg} / \mathrm{L}$ and the lowest value of the Biochemical Oxygen Demand of Pesanggrahan River water is at the observation point 1 namely the DKI Jakarta upstream urban observation point area Pesanggrahan River with a Biochemical Oxygen Demand value of $2.26 \mathrm{mg} / \mathrm{L}$. The average value of Biochemical Oxygen Demand in this Pesanggrahan River water study was $3.87 \mathrm{mg} / \mathrm{L}$.

The highest value of the observation of Chemical Oxygen Demand (COD) of Pesanggrahan River water is at observation point 36, which is the observation point downstream of the Pesanggrahan River flow with a COD value of $30.10 \mathrm{mg} / \mathrm{L}$. Watershed at this point tends not to have good ecosystems with existing door conditions. Pesanggrahan River water, where rubbish is carried by the Pesanggrahan River, is transported or accommodated (the existing condition at point 36 is a flood gate and a temporary "city park", kembangan) in the landfill and the lowest value of Chemical Oxygen Demand Pesanggrahan River water is at the observation point 1 area of the observation point downstream of the Pesanggrahan River with a Chemical Oxygen Demand value of $3.25 \mathrm{mg} / \mathrm{L}$. This point can be said to be the cleanest point and has a tendency of Pesanggerah Watershed with a fairly good ecosystem. The average value of Chemical Oxygen Demand in this Pesanggrahan River water study was $14.23 \mathrm{mg} / \mathrm{L}$. In addition, an increase in Nitrate content in river water will result in an increase in Chemical Oxygen Demand in Pesanggrahan River water. In the analysis of Chemical Oxygen Demand values, the predictor variables of temperature and $\mathrm{pH}$, there is a tendency to have no effect on the value of Chemical Oxygen Demand, which can be seen from the results of the plot that is not spread but relatively scattered at one point. 
Table 1. Values for water quality study trends for 37 representative monitoring locations from upstream

\begin{tabular}{|c|c|c|c|c|c|c|c|c|c|c|c|c|}
\hline SAMPLE & TEMPERATURE & PH & TDS & TSS & BOD & COD & $\begin{array}{l}\text { HARDNESS } \\
(\mathrm{CaCO} 3)\end{array}$ & DO & $\begin{array}{l}\text { NITRAT } \\
\text { (NO3-) }\end{array}$ & $\begin{array}{l}\text { NITRIT } \\
\text { (NO2-) }\end{array}$ & $\begin{array}{c}\text { Fecal } \\
\text { Coliform }\end{array}$ & $\begin{array}{c}\text { Total } \\
\text { Coliform }\end{array}$ \\
\hline & ${ }^{\circ} \mathrm{C}$ & & $\mathrm{mg} / \mathrm{L}$ & $\mathrm{mg} / \mathrm{L}$ & $\mathrm{mg} / \mathrm{L}$ & $\mathrm{mg} / \mathrm{L}$ & $\mathrm{mg} / \mathrm{L}$ & $\mathrm{mg} / \mathrm{L}$ & $\mathrm{mg} / \mathrm{L}$ & $\mathrm{mg} / \mathrm{L}$ & cell $/ 10 \mathrm{~mL}$ & cell $/ 10 \mathrm{~mL}$ \\
\hline 1 & 28,00 & 7,20 & 90 & 300 & 2,26 & 3,25 & 169,80 & 3,50 & 12,00 & 0,06 & 12500 & 20600 \\
\hline 2 & 28,30 & 7,25 & 90 & 280 & 2,35 & 3,67 & 151,00 & 3,50 & 14,00 & 0,05 & 9880 & 22380 \\
\hline 3 & 28,70 & 7,40 & 120 & 192 & 2,58 & 4,80 & 148,20 & 3,40 & 18,00 & 0,03 & 10000 & 23700 \\
\hline 4 & 28,50 & 7,30 & 120 & 266 & 2,33 & 5,48 & 184,30 & 3,50 & 16,00 & 0,10 & 9980 & 22480 \\
\hline 5 & 29,00 & 7,33 & 150 & 256 & 2,72 & 5,65 & 191,10 & 3,30 & 20,00 & 0,09 & 11500 & 23960 \\
\hline 6 & 28,80 & 7,39 & 120 & 230 & 2,69 & 8,99 & 179,90 & 3,50 & 17,00 & 0,34 & 10520 & 23020 \\
\hline 7 & 28,70 & 7,46 & 120 & 275 & 2,37 & 9,60 & 171,00 & 3,40 & 19,00 & 0,42 & 12100 & 22800 \\
\hline 8 & 29,10 & 7,40 & 160 & 265 & 2,51 & 9,80 & 192,50 & 3,40 & 15,00 & 0,50 & 9600 & 22100 \\
\hline 9 & 29,30 & 7,56 & 100 & 237 & 2,31 & 9,07 & 214,50 & 3,10 & 15,00 & 0,71 & 12504 & 20900 \\
\hline 10 & 28,80 & 7,50 & 180 & 165 & 3,02 & 8,42 & 210,80 & 3,10 & 17,00 & 0,80 & 9400 & 21900 \\
\hline 11 & 29,60 & 7,60 & 90 & 290 & 3,11 & 8,45 & 191,90 & 3,00 & 15,00 & 0,75 & 12500 & 20770 \\
\hline 12 & 29,60 & 7,62 & 80 & 281 & 3,20 & 8,60 & 205,00 & 3,10 & 19,00 & 0,88 & 8950 & 19400 \\
\hline 13 & 29,80 & 7,61 & 120 & 274 & 3,00 & 9,21 & 188,40 & 2,90 & 19,00 & 0,79 & 9100 & 18530 \\
\hline 14 & 30,00 & 7,80 & 90 & 257 & 2,93 & 9,67 & 183,00 & 2,80 & 20,00 & 0,73 & 9350 & 17600 \\
\hline 15 & 29,40 & 7,74 & 180 & 140 & 3,48 & 10,48 & 190,30 & 2,60 & 25,00 & 0,60 & 9100 & 16100 \\
\hline 16 & 29,80 & 7,76 & 120 & 183 & 3,70 & 10,12 & 191,40 & 2,70 & 26,00 & 0,77 & 8660 & 16820 \\
\hline 17 & 29,40 & 7,50 & 120 & 182 & 3,51 & 11,84 & 218,10 & 2,80 & 30,00 & 0,95 & 7500 & 16300 \\
\hline 18 & 29,20 & 7,81 & 120 & 186 & 3,24 & 10,65 & 216,00 & 2,60 & 28,00 & 0,92 & 8110 & 14600 \\
\hline 19 & 28,70 & 7,71 & 110 & 210 & 3,86 & 11,55 & 207,40 & 2,60 & 28,00 & 1,01 & 7025 & 13800 \\
\hline 20 & 28,80 & 7,85 & 100 & 190 & 3,88 & 11,79 & 218,20 & 2,80 & 26,00 & 1,20 & 8540 & 12300 \\
\hline 21 & 29,20 & 7,81 & 100 & 180 & 3,82 & 12,51 & 194,50 & 2,60 & 24,00 & 1,19 & 8330 & 11000 \\
\hline 22 & 28,60 & 7,80 & 100 & 180 & 4,02 & 12,28 & 209,40 & 2,70 & 31,00 & 1,28 & 8640 & 10300 \\
\hline 23 & 29,00 & 7,81 & 120 & 140 & 4,92 & 13,06 & 227,00 & 2,50 & 32,00 & 1,30 & 7990 & 6400 \\
\hline 24 & 29,50 & 7,95 & 100 & 133 & 5,21 & 13,23 & 242,10 & 2,60 & 28,00 & 1,18 & 7560 & 8800 \\
\hline 25 & 29,60 & 8,10 & 130 & 140 & 5,33 & 13,99 & 304,40 & 2,60 & 29,00 & 1,34 & 7720 & 9100 \\
\hline 26 & 29,60 & 8,15 & 100 & 120 & 5,48 & 13,10 & 314,50 & 2,70 & 40,00 & 1,40 & 7000 & 8900 \\
\hline 27 & 30,40 & 8,40 & 160 & 22 & 5,50 & 14,20 & 368,20 & 2,20 & 42,00 & 2,80 & 5500 & 8500 \\
\hline 28 & 30,60 & 8,30 & 300 & 25 & 5,11 & 23,66 & 332,10 & 2,10 & 35,00 & 3,20 & 3010 & 5000 \\
\hline 29 & 30,80 & 8,16 & 330 & 20 & 4,96 & 24,10 & 382,10 & 2,50 & 38,00 & 2,90 & 2440 & 4900 \\
\hline 30 & 30,50 & 8,24 & 290 & 40 & 4,73 & 24,80 & 378,80 & 2,40 & 38,00 & 2,84 & 1980 & 4600 \\
\hline 31 & 30,00 & 8,30 & 300 & 25 & 4,75 & 24,00 & 366,30 & 2,30 & 42,00 & 3,10 & 2370 & 4800 \\
\hline 32 & 29,60 & 8,31 & 230 & 44 & 4,89 & 23,78 & 417,00 & 2,40 & 50,00 & 3,30 & 2220 & 4200 \\
\hline 33 & 30,10 & 8,39 & 240 & 60 & 4,94 & 26,63 & 405,10 & 2,10 & 55,00 & 3,60 & 1900 & 3600 \\
\hline 34 & 30,00 & 8,29 & 260 & 56 & 5,10 & 28,66 & 439,00 & 2,30 & 60,00 & 3,44 & 1870 & 3300 \\
\hline 35 & 29,70 & 8,27 & 240 & 33 & 4,71 & 27,40 & 429,40 & 2,20 & 52,00 & 3,68 & 1660 & 2700 \\
\hline 36 & 30,10 & 8,40 & 210 & 20 & 5,21 & 30,10 & 462,20 & 2,00 & 54,00 & 3,41 & 1600 & 2800 \\
\hline 37 & 30,20 & 8,70 & 400 & 15 & 5,44 & 30,07 & 450,00 & 2,00 & 57,00 & 4,00 & 1500 & 2800 \\
\hline
\end{tabular}




\section{Total Dissolved Solid (TDS)}

Conceptually, the amount of dissolved solids in the water will affect the light entering the water or can be said to test how much light will be inhibited when the dissolved solids are higher. The higher the value of Total Dissolved Solid, the greater the content of solids contained in water and the less light that can enter the water. This can result in decreased photosynthetic activity by chlorophyll organisms that are in the water.

The highest value of Total Dissolved Solid observation is at observation point 37, which is the observation area downstream of the Pesanggrahan River with a Total Dissolved Solid value of $400 \mathrm{mg}$ / L. This observation point area is a branching point with the mookervart cengkareng / dog mogot river flow, so it can be said that Mookervart River water quality level is much lower compared to Pesanggrahan River water quality with the changes in result Total Dissolved Solid which is quite significant and the lowest value is at point 12 or at the observation point of the TPU (another name for a communal landfill) soil with a Total Dissolved Solid value of $80 \mathrm{mg} /$ L. The average value of Total Dissolved Solid in this Pesanggrahan River water study was $161.89 \mathrm{mg} / \mathrm{L}$. The high value of dissolved solids is generally caused by river areas that are close to residential areas or are in river branching areas, especially if the river has lower water quality than other river flows, therefore, that domestic waste flows into the river and increases the number of particles dissolved.

\section{Total Suspended Solid (TSS)}

The highest value from the observation of Total Suspened Solid (TSS) is at observation point 1, which is the urban upstream observation point area of DKI Jakarta Pesanggrahan River with a total Suspended Solid value of $300 \mathrm{mg} / \mathrm{L}$, and the lowest value is at point 37 or at the observation point downstream of the Pesanggrahan River with a Total Suspended Solid value of $15 \mathrm{mg} / \mathrm{L}$. The average value of TSS in this Pesanggrahan River water study was $159.75 \mathrm{mg}$ / L.

\section{Nitrate and Nitrite}

The highest value of observations of Nitrate content (as NO3-) is at observation point 33 with a Nitrate value of $60.00 \mathrm{mg} / \mathrm{L}$. The high value of Nitrate at this point can be caused by the amount of Domestic Waste discharges of the apartments and some factory wastes around the area of the observation point, and the lowest value is at point 1 or at the urban upstream observation point in DKI Jakarta Pesanggrahan River with a Nitrate value of $12.00 \mathrm{mg} / \mathrm{L}$. The average value of TSS in this Pesanggrahan River water study was $29.89 \mathrm{mg} / \mathrm{L}$.

The highest value of the observed Nitrite (as NO2-) is at observation point 37, which is the observation area downstream of the Pesanggrahan River with a Nitrit value of $4.00 \mathrm{mg} / \mathrm{L}$, and the lowest value is at point 1 or at the Jakarta urban upstream observation point Sungai Pesanggrahan with a Nitrite value of $0.03 \mathrm{mg} / \mathrm{L}$. The average value of Nitrite content in the Pesanggrahan River water study was $1.50 \mathrm{mg} / \mathrm{L}$.

The low content of Nitrates and Nitrites in the surface layer is because in the surface layer of the river the available oxygen is quite abundant in the presence of oxygen diffusion from the atmosphere. With the help of bacteria, the oxygen will oxidize Nitrites into Nitrates, therefore, the Nitrite content in the Nitrite layer becomes Nitrate and the Nitrite content in the surface layer becomes small. Thus, the value of the Nitrite content is inversely proportional to the value 
of the oxygen content in the water. This can be proven by reviewing the value of Dissolved Oxygen (DO) and also the value of the fecal content and Total Coliform which are interrelated.

\section{Hardness}

Hardness is derived from salt chemical compounds in the form of cations and anions, causing the water quality of the Pesanggrahan River to become turbid and have a density when viewed with the naked eye.

The highest value of the observation of the Pesanggrahan River water hardness is at observation point 36 which is the observation point of the downstream floodgate Pesanggrahan River (Kembangan) with a water hardness value of $462.20 \mathrm{mg} / \mathrm{L}$ which could be due to the floodgates holding up the flow of the Pesanggrahan River so that sediment occurs at the bottom of the river, which causes the depth of the existing deposits. Deposits that have a lower density than water usually arise to the surface, which causes the physical condition of the water to become turbid and hardness in the water to appear and the lowest value is at point 3 or at a location near the downstream of the Pesanggrahan River with a Hardness Water value of $148.20 \mathrm{mg} / \mathrm{L}$ and this condition occurs because this condition is due to the concentration and activity of domestic and industrial waste production which is still minimal, but supported by low water flow relatively swift compared This part of the sentence does not make sense and the meaning is not clear. Consider revising, the average value of hardness content in the Pesanggrahan River water study was $263.38 \mathrm{mg} / \mathrm{L}$. This shows the Pesanggrahan River water flow factor which has a relatively low speed in the srengseng area downstream of the Pesanggrahan River located in the city park area kembangan / kemiri market, which is evidenced by the relatively high hardness level of the Pesanggrahan River and the flow of the Pesanggrahan River does not carry over.

\section{Fecal Coliform and Total Coliform}

The highest value of Fecal Coliform observations of Escherichia Coli bacteria or often called E-coli is at observation point 9, which is the RPTRA Anggrek Bintaro observation point with a Fecal Coliform value of 12,504 cells / $100 \mathrm{~mL}$ (this area is a densely populated residential / residential area) and the lowest value is located at point 37 or downstream of the Pesanggrahan River with a Fecal Coliform value of 1,500 cells / 100mL. The average value of Fecal Coliform in the Pesanggrahan River water study is 7,300 cells / $100 \mathrm{~mL}$.

The highest value of bacterial Total Coliform observations was at observation point 5 , namely the observation point of Pondok Pinang toll gate area with a Fecal Coliform value of 23,960 cells / $100 \mathrm{~mL}$ (this area has a dense urban forest / green land with a deep cliff wall that is deep enough, so still there are many natural ecosystems in it), and the lowest value is at points 36 and 37 or downstream of the Pesanggrahan River with a Fecal Coliform value of 2,800 cells / $100 \mathrm{~mL}$. The average value of Fecal Coliform in the Pesanggrahan River water study is 13,290 cells / $100 \mathrm{~mL}$. The results of the review of the existing field conditions, the value of bacterial coliform which is above the average value is a residential / residential area. Where in the area of domestic waste comes from organic sewage wastes, which is known if bacteria such as EColi can multiply rapidly or sourced from the dung of living things (organic).

Decrease in the value of Fecal Coliform is directly proportional to the decrease in the value of Total Coliform, and inversely proportional to the value of Pesanggrahan River water hardness. Drastic decline in organisms such as bacteria / coliforms is generally caused by the content of salt chemical compounds that are sourced from the production of industrial wastes and also detergent / domestic waste, which are the constituent compounds. 

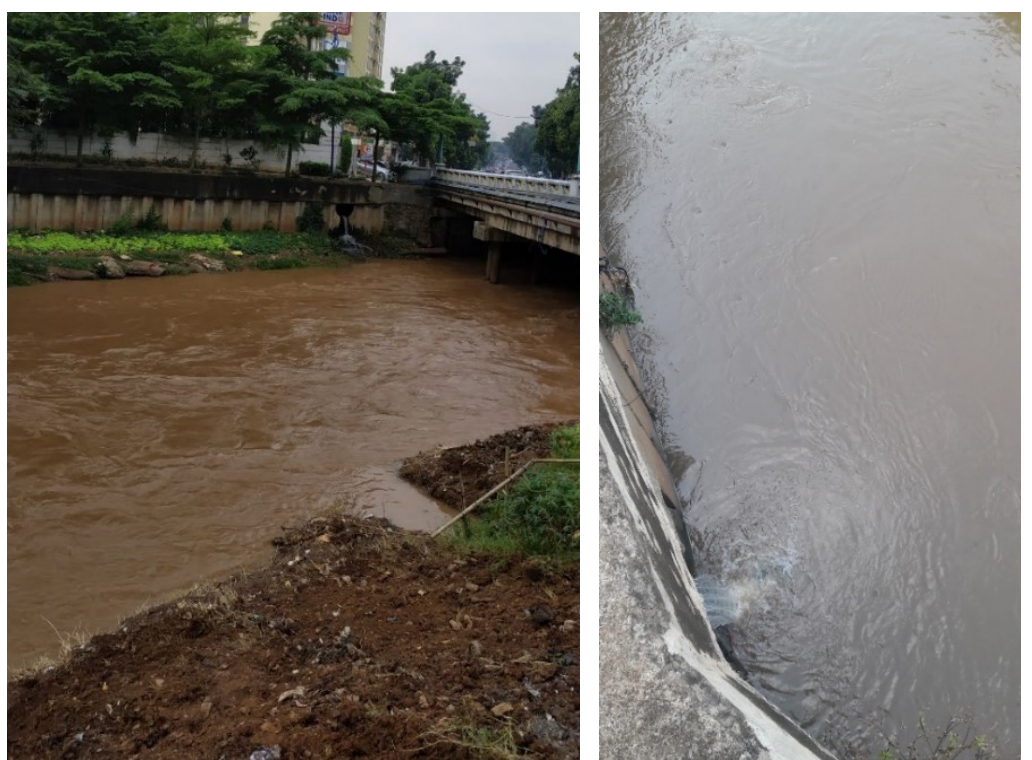

Figure 1. (Domestic Waste) Water canal of an apartment building in the Pesanggrahan River.

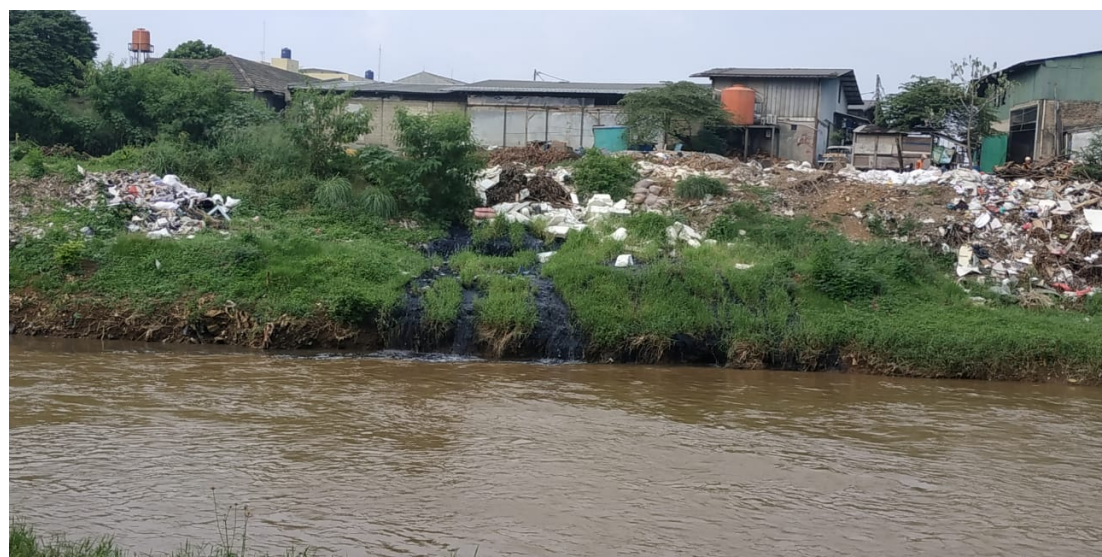

Figure 2. (Industrial Waste) Home Textile Industry Waste (Washing and Staining of Jeans) Black Solid Color Flowing Into Pesanggrahan River Water Flow.

\subsection{Factor of Declining Pesanggrahan River Water Quality}

The decline in the water quality of the Pesanggrahan River is due to the large number of violations committed by the community, especially many who use residential buildings that have become business locations that produce domestic wastes discharged into the Pesanggrahan River. As an example of the Kebayoran Lama and Pesanggrahan area, houses around the Pesanggrahan Watershed are used as the location of the textile industry where the disposed wastes are directly channeled into the Pesanggrahan River, although in their designation and licensing they are both are the same. Considering the can be considered as industrial land that 
is illegal and violates spatial planning. Decreasing water quality in the Pesanggrahan River has accumulated chemical contents so that the value of water quality will get worse in the downstream of the river. The decline in the water quality of the Pesanggrahan River caused in large part by domestic waste which is die to the poor sanitation and drainage system in the Pesanggrahan River Region. Where houses dispose their domestic wastes directly into drainage connected to the Pesanggrahan River without any process of processing waste either independently or communally the water does not meet the applicable quality standards.

The wastewater disposal system is in the form of domestic (household) wastewater, which domestic wastewater management is generally carried out by using a local sanitation system (on site sanitation) in the form of latrines, which are managed individually or communally, which are equipped with septic or cubluk tanks. Meanwhile, if using a centralized sanitation system (off site sanitation), the implementation requires a considerable amount of cost also in its maintenance, so that the use of the existing centralized sanitation system is estimated to only be able to serve residents living in the DKI Jakarta city.

\section{Conclusion}

The water quality of the Pesanggrahan River tends to be low and polluted. This can be seen from the observations of the colors of the Pesanggrahan River water samples compared to Aquadest or distilled water, all of which were found at the point of observation for deposits and discoloration. From the water quality index value, chemical and biological contents in the Pesanggrahan River water show that the Pesanggrahan River water is included in the polluted river category. The level of water pollution in the Pesanggrahan River is greater in the downstream river due to the accumulation which is carried by the river water flow of chemical compounds due to industrial and domestic waste from the upstream of the river. Most of the Watershed Houses are both are the same. Spatial allotment errors occur mostly in industrial activities in residential areas. The development that occurred in the Pesanggrahan Watershed area was more on the increase in the number of house buildings and the condition of vacant land to become vertical housing and commercial buildings. The development occurred almost entirely in the period of 2004 to 2010 , while in the period 2010 to 2013 more changes were made in the structure of the Pesanggrahan River flow, namely the widening and straightening of the river.

\section{References}

1. American Public Health Association. (1999). Standard Methods for the Examination of Water and Wastewater (20th ed.). Baltimore: American Public Health Association.

2. Campbell, J., \& Peterson, D. (2010). Determination of water hardness from common water sources using flame atomic absorbance spectrometry. Concordia College Journal of Analytical Chemistry 1, 4-8.

3. EPA. (2012). Total Alkalinity. In Water: Monitoring and Assessment. Retrieved from $\mathrm{http}: / /$ water.epa.gov/type/rsl/monitoring/vms510.cfm.

4. Griffiths, P. G., Hereford, R., \& Webb, R. H. (2006). Sediment yield and runoff frequency of small drainage basins in the Mojave Desert. California and Nevada: USGS Fact Sheet: Recoverability and Vulnerability of Desert Ecosystems. Retrieved from https://www.fondriest.com/environmentalmeasurements/parameters/water-quality/water-temperature/ 
5. Kannel, P., Lee, S., Lee, Y.-S., Kanel, S., \& Khan, S. (2007). Application of Water Quality Indices and Dissolved Oxygen as Indicators for River Water Classification and Urban Impact Assessment. Environ Monit Assess, 132:93-110.

6. Kozaki, D., Ozaki, T., Nakatani, N., Mori, M., \& Tanaka, K. (2014). Utilization of Ion-Exclusion Chromatography for Water Quality Monitoring in a Suburban River in Jakarta, Indonesia. Water, 1945-1960.

7. Lenntech. (2018). Magnesium and water: reaction mechanisms, environmental impact and health effects. Retrieved May 25, 2019, from www.lenntech.com: Magnesium and water: reaction mechanisms, environmental impact and health effects

8. Lumaela, A., Otok, B., \& Sutikno. (2013). Pemodelan Chemical Oxygen Demand (COD) Sungai di Surabaya Dengan Metode Mixed Geographically Weighted Regression. JURNAL SAINS DAN SENI POMITS, 2, 100105.

9. Maryono, A. (2017). Water Resources Management Reform. Yogyakarta: Gadjah Mada University Press.

10. Maryono, A. (2018). River Border Area Management With Integral Approach: Regulation, Institutional, Spatial, Social, Morphological, Ecological, Hydrological and Engineering. Yogyakarta: Gadjah mada University Press.

11. Nazir, M. (2009). Metode Penelitian. Jakarta: Perpustakaan Nasional.

12. Odum, E. (1971). Fundamental of Ecology. Philadelphia: W.B. Saunder Com.

13. Scannell, P. W., \& Jacobs, L. L. (2001). Technical Report: No. 01-06 Effects of Total Dissolved Solids on Aquatic Organisms. Alaska: Alaska Department of Fish and Game: Division of Habitat and Restoration.

14. Wood, M. S. (2014). Estimating suspended sediment in rivers using acoustic Doppler meters. Retrieved Mei 25, 2019, from U.S. Geological Survey Fact Sheet: https://www.fondriest.com/environmentalmeasurements/parameters/water-quality/turbidity-total-suspended-solids-water-clarity/

15. World Health Organization. (2003). pH in Drinking-water. In Guidelines for drinking-water quality. Retrieved 05 26, 2019, from http://www.who.int/water_sanitation_health/dwq/chemicals/en/ph.pdf.

16. YUDO, S., \& SAID, N. (2018). Ciliwung River Water Quality Status in the DKI Jakarta Region. Jurnal Teknologi Lingkungan, 13-22. 